\title{
The digestibility and nutritive value of sugar beet top silage for sows
}

\author{
Maija-Lirsa Salo and Elisa LaAkso \\ Department of Animal Husbandry, University of Helsinki, 00710 Helsinki 71
}

\begin{abstract}
The digestibility of beet top silage made from tops harvested with a mower chopper was determined with five adult, pregnant sows. Two rations of $6 \mathrm{~kg} /$ day (Trial I) and $2 \mathrm{~kg} /$ day (Trial II) were tested, with the dry matter comprising 48 (I) and $20 \%$ (II) of the total dry matter of the barley-based diet. The average digestibilities of silage were 68.6 (I) and $69.3 \%$ (II) for organic matter and 71.0 (I) and $64.4 \%$ (II) for crude protein. The pepsin-solubility of crude protein was $85 \%$.

The calculated energy value was $2.21 \mathrm{Mcal}$. ME/kg DM, corresponding to 0.60 f.u./kg DM (f.u. = C.7 starch units), and the protein value $142 \mathrm{~g} \mathrm{DCP} / \mathrm{kg}$ DM.

The amino acid composition of crude protein of both fresh and ensiled tops was better than that reported for beet tops cut at ground level. The composition changed very little during ensilage.

Beet top silage is rich in all required minerals except phosphorus. The oxalic acid converts silage $\mathrm{Ca}$ and even extra $\mathrm{Ca}$ to an indigestible form, but does not impair the digestibility of $\mathrm{Mg}$. The large amounts of $\mathrm{K}$ and $\mathrm{Na}$ raise the $\mathrm{pH}$ of urine to a high level. The trace element contents of beet tops are well above the established requirements for pigs and the excess is secreted in the faeces.
\end{abstract}

\section{Introduction}

Ensiled sugar beet tops harvested with mower chopper have a high nutritive value, even though a large part of their soluble material has passed off with the effluent or fermented to acids. This sort of silage contains more crude protein and less ash (soil) than silage made from tops cut at ground level (SALO et al. 1974, 1975).

The nutritive value of beet top silage for cattle is well known. The digestibility of organic matter in vitro has been found to vary between 77 and $80 \%$, corresponding to an energy value of 0.8 f.u. $/ \mathrm{kg}$ dry matter (f.u. $=0.7$ starch units) (SALO et al. 1974, 1975). The value for pigs is poorly known and published figures refer to tops cut at ground level (PRESTHEGGE 1944, Futterw. tab. 1958, 1970, Косн 1969).

The purpose of the present study was to determine the digestibility of beet top silage for sows and, on that basis, to calculate its energy, crude protein and mineral values. 
Table 1. Chemical composition of beet top silage and barley.

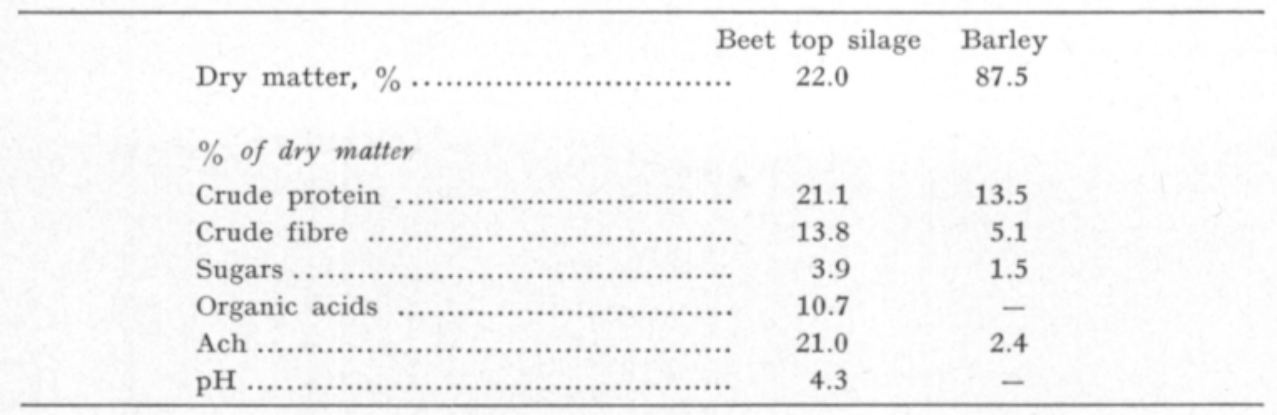

\section{Material and methods}

The sugar beet tops were ensiled without additives in a small tower-silo. The quality was good. The chemical composition of the silage and barley used in the digestibility trials is presented in Table 1.

The trials were performed with five adult pregnant Yorkshire sows having an average weight of about $260 \mathrm{~kg}$. The sows were kept in their own farrowing pens, on a concrete floor without bedding. The feed was given twice a day as flour mixed with water.

For the two weeks before the trials the sows were fed the same barley meal and silage investigated in the trials. The feeding during trials differed from that before only in the absence of the mineral supplement and the administration of fixed rations. In the first feeding trial the daily rations were $1.5 \mathrm{~kg}$ barley meal and $6.0 \mathrm{~kg}$ beet top silage; in the second, $1.9 \mathrm{~kg}$ barley and $2.0 \mathrm{~kg}$ silage. In both trials the pigs consumed all the feed given.

The preliminary period was four days and the collection period the following three days. The sows were kept in their regular pens, and were watched over day and night, so that the faeces could be collected immediately and trampling or contamination with urine avoided.

The dry matter content of silage and faeces was determined daily at $100^{\circ} \mathrm{C}$ The samples for analysis were dried in vacuum at $40^{\circ} \mathrm{C}$. Analyses were made by standard methods or by SALo's methods $(1965,1969)$. Cations were determined with an AA - 1000 Techtron atomic absorption spectrophotometer and phosphorus by the method of TAYSSKY and SHORR (1953). The determination of amino acids was made at the State Institute of Agricultural Chemistry.

\section{Results and discussion}

\section{Energy and protein}

The digestibility coefficients for barley were taken from the Feed Tables on the basis of its composition (81\% digestibility for organic matter and $77 \%$ for crude protein). The digestibility coefficients for the beet top silage, calculated by subtraction, are given in Table 2 . 
Table 2. Digestibility of beet top silage for sow, $\%$.

\begin{tabular}{|c|c|c|c|c|c|}
\hline \multirow{2}{*}{ Sow $\mathrm{I}$} & \multirow{2}{*}{ No } & \multicolumn{2}{|c|}{ Organic matter } & \multicolumn{2}{|c|}{ Crude protein } \\
\hline & & Diet 1 & Diet 2 & Diet 1 & Diet 2 \\
\hline & 1 f.w. & 66.0 & 71.6 & 64.7 & 56.6 \\
\hline & 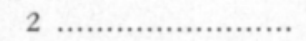 & 68.8 & 67.1 & 73.0 & 71.7 \\
\hline & 3 .......................... & 73.7 & 80.4 & 75.2 & 74.8 \\
\hline & 4 ....................... & 72.4 & 59.6 & 75.4 & 61.0 \\
\hline & 5 f....................... & 63.3 & 67.7 & 66.5 & 58.0 \\
\hline & $\overline{\mathbf{x}} \ldots \ldots \ldots \ldots \ldots \ldots \ldots \ldots$ & 68.8 & 69.3 & 71.0 & 64.4 \\
\hline
\end{tabular}

The average digestibilities for organic matter agreed well for the six $\mathrm{kg}$ and two kg daily rations, those for crude protein poorly. Individual differences between pigs showed up especially in trial II, perhaps because of the shortness of the collection period. In trial I, however, three days seemed to be enough, since the faeces were soft, the amounts large and the variation between days little. The results of trial I are also more reliable in that the silage dry matter comprised $48 \%$ of that of the diet, whereas in diet II it comprised only $20 \%$. A comparison was made earlier between -four- and seven-day collection periods, and the four-day period was found to give the same digestibility coefficient as the longer period.

Examination of the faeces revealed individual differences between pigs in chewing the silage, and the efficiency of chewing was reflected in the digestibility coefficients.

The digestibility of the organic matter of beet silages from tops cut at ground level is reported to be $61-69 \%$ and the digestibility of the crude protein 41-58\% (Presthegge 1944, Futterw. tab. 1958, Косн 1969). The reason for the higher value for crude protein in the present study appears to lie in the fact that the content of protein in the present tops is nearly twice that in tops cut at ground level, and that the protein is more digestible. The high pepsin-solubility of the silage protein investigated here - on average $85 \%$ - supports the result in vivo. A similarly high pepsin-solubility for fresh and ensiled beet tops has also been found earlier (SALO et al. 1975).

On the basis of digestible crude components (disregarding the crude fat, which in silages consists principally of lactic and acetic acids), the calculated energy value was $2.21 \mathrm{Mcal}$. $\mathrm{ME} / \mathrm{kg}$ dry matter and the corresponding f.u. value 0.60 f.u. $/ \mathrm{kg}$ DM $(0.27 \times$ Mcal.-value, according to the ratio Mcal./f.u. of beet tops, NJF's Fodermiddeltab. 1969). The calculated value is in good agreement with the values reported for pure good quality beet silage and is about $35 \%$ better than values for silages contaminated with soil.

The digestible crude protein value, $142 \mathrm{~g} / \mathrm{kg} \mathrm{DM}$, is twice that repoted in the Feed Tables. An explanation of the difference has been offered above.

\section{Amino acids}

The amino acid composition of fresh beet tops (averages of equivalent results from two years), beet top silage, and the barley are given in Table 3 . 
The amino acid content of tops seems to change very little during ensilage. The proportions of lysine as well as of many other essential amino acids were a good third higher than the values given in the Feed Tables (Futterm. tab. 1969, 1970). Cystine was exceptional with a similar or lower proportion. Accordingly, the amino acid composition of the crude protein of the leaves is better than that of tops cut at ground level.

The proportion of lysine is so high that the two-kilo ration of beet silage corresponds to nearly $150 \mathrm{~g}$ soybean meal and raises the total lysine content of a barley-oat diet to about $0.6 \%$ of dry matter, which suffices for the pregnant sow (Zimmerman 1974, SchWark et al. 1975). Likewise the silage makes up for deficiencies of other essential amino acids in the diet. Total crude protein is supplied at the recommended level, too.

The two-kilo ration of silage does not increase the water content of faeces. The six-kilo ration does, and the cleaning of pens is consequently more laborious.

\section{Minerals}

Sugar beet tops are rich in all minerals except phosphorus (SALO et al. $1974,1975)$. About $75 \%$ of the ash of fresh tops and $60 \%$ of that of silages is soluble in $1 \mathrm{~N}$ hydrochloric acid.

The mineral composition of diets I and II is given in Table 4. All the minerals are derived from silage and barley. Deficiencies as measured against accepted standards occurred only in phosphorus, and in diet II also in calcium. The contents of many of the minerals were several times above established standards.

Table 3. The amino acid composition of fresh and ensiled sugar beet tops and barley $(\mathrm{g} / 16 \mathrm{~g} \mathrm{~N})$.

\begin{tabular}{|c|c|c|c|}
\hline & \multicolumn{2}{|c|}{ Sugar beet tops } & \multirow[t]{2}{*}{ Barley } \\
\hline & Fresh & Ensiled & \\
\hline $\begin{array}{l}\text { Crude protein, \% of DM } \ldots \ldots \ldots \ldots \ldots \ldots \ldots \\
g / 16 g \mathrm{~N}\end{array}$ & 20.0 & 21.0 & 13.5 \\
\hline 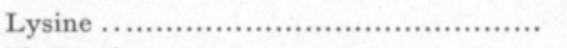 & 5.4 & 6.1 & 4.1 \\
\hline 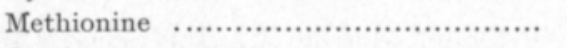 & 1.5 & 1.7 & 1.7 \\
\hline 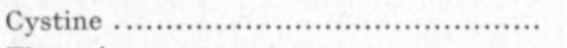 & 0.8 & 0.7 & 1.7 \\
\hline 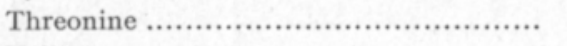 & 4.5 & 4.1 & 4.3 \\
\hline 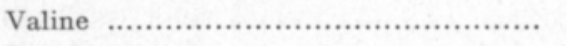 & 4.9 & 4.9 & 4.9 \\
\hline Leucine ......................................... & 7.3 & 7.1 & 7.5 \\
\hline 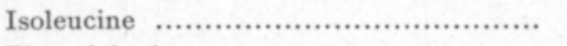 & 4.1 & 4.1 & 3.8 \\
\hline 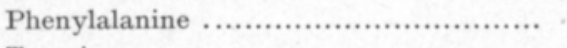 & 4.7 & 4.5 & 5.3 \\
\hline 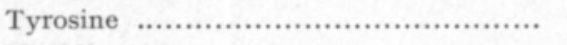 & 3.3 & 3.4 & 2.4 \\
\hline 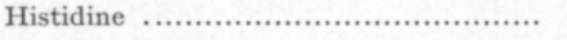 & 2.3 & 2.5 & 2.3 \\
\hline 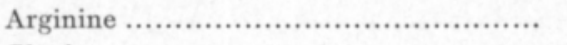 & 4.8 & 3.2 & 4.5 \\
\hline 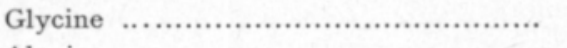 & 5.3 & 5.3 & 4.5 \\
\hline 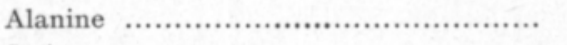 & 5.4 & 5.5 & 4.4 \\
\hline 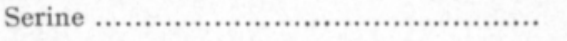 & 4.5 & 4.0 & 4.9 \\
\hline 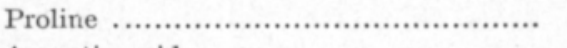 & 4.3 & 4.2 & 11.8 \\
\hline 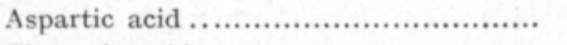 & 8.9 & 7.9 & 7.0 \\
\hline 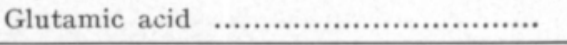 & 10.0 & 9.2 & 23.6 \\
\hline
\end{tabular}


Table 4. Mineral composition and the average digestibility of minerals in diets I and II.

\begin{tabular}{|c|c|c|c|c|c|}
\hline & & \multicolumn{2}{|c|}{$\mathrm{g} / \mathrm{kg}$ dry matter } & \multicolumn{2}{|c|}{ Digestibility, \% } \\
\hline & & I & II & I & II \\
\hline Ash & (n........................ & 117.13 & 60.68 & 61 & 32 \\
\hline $\mathrm{Ca}$ & (n....................... & 6.69 & 3.45 & -13 & -7 \\
\hline $\mathrm{P}$ & (........................ & 2.59 & 2.81 & 22 & 27 \\
\hline $\mathrm{Mg}$ & ............ & 5.28 & 2.72 & 20 & 14 \\
\hline $\mathrm{Na}$ & 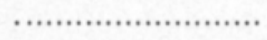 & 4.12 & 1.97 & 96 & 91 \\
\hline $\mathbf{K}$ & (n..................... & 23.94 & 11.92 & 96 & 86 \\
\hline $\mathrm{Fe}$ & ……………… & 0.89 & 0.50 & -9 & -11 \\
\hline $\mathrm{Cu}$ & 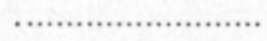 & 0.017 & 0.011 & 12 & 8 \\
\hline Mn & 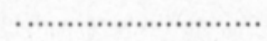 & 0.22 & 0.10 & 6 & 0 \\
\hline $\mathrm{Zn}$ & ........................ & 0.35 & 0.16 & 10 & 0 \\
\hline
\end{tabular}

The average digestibilities of minerals are also shown in Table 4. The results show the following:

$\mathrm{C}$ a l c i u mas excreted in faeces over the amount consumed in feeds. In trial I the average loss was $2.2 \mathrm{~g} \mathrm{Ca} / \mathrm{sow} /$ day, in trial II, $0.5 \mathrm{~g} \mathrm{Ca} / \mathrm{sow} /$ day, thus indicating that loss was increased with an increase in silage, although the actual intake of calcium was higher. The explanation lies with oxalic acid, which binds extra calcium in addition to that of silage. The results are in agreement with Presthegge's (1944) observation that beet top silage induces symptoms of rachitis in growing pigs. Consequently, calcium supplementation is necessary with beet top feeding. The excretion of calcium in urine was very small, about $\mathbf{2}-\mathbf{5} \mathbf{~ m g / l i t e r . ~}$

$\mathrm{Phosphorus}$ from silage was digested somewhat more poorly than that from barley. Both diets contained only about half of the phosphorus requirement of the sow. The secretion in urea was highly dependent on the sampling time, the range being about $35-250 \mathrm{mg} \mathrm{P} /$ litre.

$\mathrm{M}$ a g n e si u m was supplied in a large overdose. Its digestibility was good, and better for silage than for barley. Oxalic acid did not seem to impair the utilization of magnesium. Secretion in urine was about $45 \mathrm{mg} \mathrm{Mg} / 1$ with diet I and $35 \mathrm{mg} / \mathrm{l}$ with diet II.

Potassium and sodium occurred very abundantly and were absorbed almost completely. Correspondingly, their contents in urine were high, and the $\mathrm{pH}$ of urine was elevated. With diet $\mathrm{I}$ the $\mathrm{pH}$ was about 7.9, with diet II about 7.6. When the sows received barley with a normal mineral supplement and straw or hay, the $\mathrm{pH}$ of the urine was $6.5-6.9$.

The results for i r o n were variable and unreliable because the $\mathrm{Fe}$ of soil interfered with the determinations. If the negative result depended only on the oxalic acid, the digestibility figures for diets I and II should be reversed.

The digestibilities of the other trace elements were also poor. Again, one would expect the results for diets I and II to be reversed if the digestibility had decreased because of oxalic acid. It seems more reasonable that the digestibility was poor because the sows consumed a large overdose 
of trace minerals from silage and mineral supplement before the trials. Since the excess of trace elements is secreted in faeces (KIRCHGESSNER et al. 1961), their digestibility appeared poor. In the urine trace minerals were observed only in minimal amounts.

\section{REFERENCES}

Futtermitteltabellenwerk, 1970,460 p. Berlin.

Futterwerttabellen der DLG - Schweine. 1958. 31 p. Frankfurt am Main.

Kirchgessner, M. \& OelschläGER, W. 1961. Der Einfluss verschiedener Zinksulfat-Zulagen auf die Retention von Mengen- und Spurenelementen bei wachsenden Schweinen. Arch. Tierernähr. 11: 310-320.

Косн, G. 1969. Grünfuttersilagen. Handbuch der Futtermittel I: 263-360. Hamburg und Berlin. NJF's Fodermiddeltabel. 1969. 40 p. Gjøvik.

Presthegge, K. 1944. A. I. V.-før av førbeteblad til slagtegriser. Norges Landbr. høgsk. Føringsfors. 56. 35 p.

Salo, M.-L., 1965. Determination of carbohydrate fractions in animal foods and faeces. Acta Agr. Fenn. 105: 1-102.

- - 1975. Sokerijuurikkaan naatit rehuna. Karjatalous 10/1975: 35-36.

- - \& Kotilainen, K. 1969. Determination of free and combined plant acids. J. Scient. Agric. Soc. Finl. 41: 277-289.

- - - \& Sormunen, R. 1974. Sokerijuurikkaan naatit ja niistä valmistettu säilörehu. Abst. Sugar beet tops and beet top silage. J. Scient. Agric. Soc. Finl. 46: 88-102.

SchWark, H.-J., Zebrowski, Z. \& OvsJannikov, V. N. 1975. Internationales Handbuch der Tierproduktion. Schweine. 784 p. Berlin.

TAUSSKy, H. H. \& SHORR, E. 1953. A microcolorimetric method for the determination of inorganic phosphorus. J. Biol. Chem. 202: 675-685.

Zimmerman, D. 1974. Swine nutrition research. Feedstuffs 46, No 39:4.

Ms received April 14, 1977

\section{SELOSTUS}

\section{Naattisäilörehun sulavuus ja rehuarvo emakoilla}

Maija-Lissa Salo ja Elisa Laakso

Kotieläintietecn laitos, Helsingin yliopisto.

Viidellä täysikasvuisella, tiineellä yorkshire-emakolla tutkittiin kelasilppurilla korjatusta sokerijuurikkaan naatista tehdyn säilörehun sulavuutta $6 \mathrm{~kg} / \mathrm{pv}$ (I) ja $2 \mathrm{~kg} / \mathrm{pv}$ (II) tasoilla. Perusrehuna oli ohra. Differenssină laskien saatiin naattisäilörehun orgaanisen aineen sulavuudeksi keskimäärin 68.8 (I) ja 69.3 (II) \% ja raakavalkuaisen sulavuudeksi 71.0 (I) ja 64.4 (II) \%. Raakavalkuaisen pepsiini-liukoisuus oli $85 \%$.

Keskimääräisestä sulavuudesta laskien tuli säilörehun energia-arvoksi 2.21 Mcal. ME eli $0.60 \mathrm{ry} / \mathrm{kg} \mathrm{ka}$ ja valkuaisarvoksi $142 \mathrm{~g}$ srv $/ \mathrm{kg}$ ka.

Raakaproteiinin välttämättőmien aminohappojen pitoisuudet olivat rikkipitoisia lukuunottamatta noin kolmannesta paremmat, mitä kantoineen listitylle naatille on ilmoitettu. Säilöntä ei mainittavasti muuttanut aminohappopitoisuuksia.

Naattisäilörehu sisälsi fosforia lukuunottamatta hyvin runsaasti kivennäisiä. Sika ei pystynyt käyttämään hyväkseen naatin kalsiumia, vaan oksaalihappo sitoi myōs ylimääräistä kalsiumia. Kaliumia ja natriumia oli runsaasti, ne imeytyivät hyvin ja nostivat virtsan pH:n korkeaksi. Hivenaineita oli paljon yli sian ohjenormien ja ylimäärä erittyi sonnassa. 